\title{
Neriidae (Diptera: Schizophora) of the Northeastern Brazil: new records and an identification key
}

\author{
Tatiana A. Sepúlveda ${ }^{1 *}$, Lucas R. P. Gomes ${ }^{2} \mathbb{C D}_{\text {\& }}$ \& Francisco Limeira-de-Oliveira ${ }^{3} \mathbb{C}$ \\ ${ }^{1}$ Universidade Federal do Rio de Janeiro, Departamento de Entomologia, Museu Nacional, Quinta da Boa \\ Vista, São Cristóvão, 20940-040, Rio de Janeiro, RJ, Brasil. \\ ${ }^{2}$ Universidade Federal do Paraná, Departamento de Zoologia, 81531-980, Curitiba, PR, Brasil. \\ ${ }^{3}$ Universidade Estadual do Maranhão, Laboratório de Estudos dos Invertebrados, 65604-380, \\ Caxias, Maranhão, Brasil. \\ *Corresponding author: Tatiana A. Sepúlveda, e-mail: tatiana.sepulveda.villa@gmail.com
}

\begin{abstract}
SEPÚlVEDA, T. A., GOMES, L.R.P., LIMEIRA-DE-OLIVEIRA, F. Neriidae (Diptera: Schizophora) of the Northeastern Brazil: new records and an identification key. Biota Neotropica. 20(1): e20190854. http://dx.doi.org/10.1590/1676-0611-BN-2019-0854
\end{abstract}

\begin{abstract}
Here, we provide a list of seven species collected in the Brazilian states of Ceará, Maranhão and Piauí, housed in the Coleção Zoológica do Maranhão (CZMA), Cerantichir peruana (Hennig, 1937), Glyphidops durus (Cresson, 1926), Glyphidops filosus (Fabricius, 1805), Glyphidops flavifrons (Bigot, 1886), Glyphidops vittatus (Cresson, 1912), Nerius pilifer Fabricius, 1805 and Nerius plurivittatus Bigot, 1886. Representatives of Neriidae are recorded and mapped for the first time in the states of Ceará, Maranhão and Piauí, while the species C. peruana, G. durus, G. flavifrons and G. vittatus represent new records for the Northeast Region of Brazil. A key for the identification and diagnoses of Northeastern Brazilian neriids are provided.
\end{abstract}

Keywords: Ceará, faunistic survey, Maranhão, Nerioidea, Piauí.

\section{Neriidae (Diptera: Schizophora) do Nordeste do Brasil: novos registros e uma chave de identificação}

\begin{abstract}
Resumo: Uma lista de sete espécies coletadas nos estados brasileiros do Ceará, Maranhão e Piauí é disponibilizada, baseada em material depositado na Coleção Zoológica do Maranhão (CZMA), Cerantichir peruana (Hennig, 1937), Glyphidops durus (Cresson, 1926), Glyphidops filosus (Fabricius, 1805), Glyphidops flavifrons (Bigot, 1886), Glyphidops vittatus (Cresson, 1912), Nerius pilifer Fabricius, 1805 e Nerius plurivittatus Bigot, 1886. Representantes de Neriidae são registrados e mapeados pela primeira vez nos estados do Ceará, Maranhão e Piauí, enquanto $C$. peruana, G. durus, G. flavifrons e G. vittatus representam novos registros para a Região Nordeste do Brasil. São apresentados uma chave para a identificação e diagnoses dos neríideos da Região Nordeste brasileira.
\end{abstract}

Palavras-chave: Ceará, levantamento faunístico, Maranhão, Nerioidea, Piauí.

\section{Introduction}

Neriidae is a cosmopolitan family of acalyptrate flies composed of 104 valid species classified in 16 genera (Pape et al. 2011, Sepúlveda et al. 2013a, Sepúlveda \& de Carvalho 2019, Sepúlveda \& Souza 2019, Sepúlveda et al. 2019). The first catalog of Neotropical Neriidae was published by Steyskal (1968), who listed 37 species from the region, of which 13 species were recorded for Brazil. In recent years, a number of studies on the taxonomy of Neriidae have been published, expanding the known distribution of several species (e.g., Carvalho-Filho \& Esposito 2008, Sepúlveda et al. 2013a, b, 2014, Braga et al. 2017). Currently, 17 species of Neriidae are recorded for Brazil (Sepúlveda 2019). Brazil is the largest country in the Neotropical Region and comprises a great diversity of biomes, including 14 biogeographical provinces, of which five occur in the Northeast Region: Pará, Caatinga, Cerrado, Atlantic Forest and Paraná Forest (Morrone 2015).
Three studies focused on Neriidae from a particular region in Brazil have been published in the last years: North: Carvalho-Filho \& Espósito (2008); Center-west: Calhau et al. (2017); and Northeast: Braga et al. (2017). The study of Braga et al. (2017) in Paraíba, Pernambuco and Bahia is complemented with information from this contribution, obtained after analysis of the material deposited in the Coleção Zoológica do Maranhão (CZMA) in the state of Maranhão, Brazil. The material in the CZMA collection was obtained in fieldwork at the states of Maranhão, Ceará and Piauí, between 2010 and 2017. Here, we provide a list of localities for seven species housed in the CZMA, representing the first records of Neriidae in Maranhão, Ceará and Piauí and the first records for Northeastern Brazil of Cerantichir peruana (Hennig, 1937), Glyphidops durus (Cresson, 1926), Glyphidops flavifrons (Bigot, 1886), Glyphidops vittatus (Cresson, 1912), raising to nine the number of species known to occur in Northeastern Brazil. 


\section{Materials and Methods}

The material belongs to Coleção Zoológica do Maranhão (CZMA), Brazil. The genera were identified using Buck (2010). For specific identifications, we used keys published in revisions of each genus (Sepúlveda et al., 2013b, 2014) and for the species of Nerius (lacking taxonomical revision), we used the key by Aczél (1961). Photographs were taken with an Auto-Montage Imaging System ${ }^{\circledR}$ Leica DFC 500 in the Taxonline (UFPR). Information on the distribution of the species listed in Table 1 was obtained from Aczél (1961), Steyskal (1968), Carvalho-Filho \& Espósito (2008), Sepúlveda et al. (2013b), Sepúlveda et al. (2014) and Braga et al. (2017). Distribution maps are based on records of Neriidae mostly from the Taxonomic Catalog of the Brazilian Fauna, TCBF and Braga et al. (2017); they were prepared in QGIS 3.6.0-'Noosa' software (https://www.qgis.org/en/site/) using the freely available DIVA-GIS country borders data (http://www.diva-gis.org/).

\section{Results}

Recently, Braga et al. (2017), presented the first list of species for the Brazilian Northeast, with four species. This list was mostly based on a few previous records and material collected in the states of Paraíba, Pernambuco and Bahia. Herein, new records of seven species and three genera of Neriidae in three Brazilian states are presented: Glyphidops filosus (Fabricius, 1805) for Ceará, Maranhão and Piauí; Nerius pilifer Fabricius, 1805 for Maranhão and Piauí; and Cerantichir peruana (Hennig, 1937), Glyphidops durus (Cresson, 1926), Glyphidops flavifrons (Bigot, 1886), Glyphidops vittatus (Cresson, 1912) and Nerius plurivittatus Bigot, 1886 for Maranhão, raising to nine the number of species recorded for the Brazilian Northeast (Figures 1 and 2). Also, the distributional maps of the Neriids species from the Brazilian Northeast are presented (Figure 3), including the seven species found in our survey and the other two species previously known to Brazilian Northeast (Eoneria blanchardi Aczél, 1951 and Glyphidops carrerai Aczél, 1961, Figures 3B and 3C respectively).

\section{Key for the species of Neriidae from the Northeast Region of Brazil}

1. Six dorsocentral setae. Syntergite $1+2$ with one long lateral seta and a few conspicuous marginal setae not inserted in a protuberance. Antennal base pale brown and opaque ........................ E. blanchardi 1 '. One dorsocentral seta. Syntergite $1+2$ without lateral seta and thick marginal setae gathered in a protuberance. Antennal base shiny, if opaque, black

2. Presutural scutum and antepronotal ridge, distinctly anterior to postpronotal carina. Pedicel elongate, length at least twice the width. Occiput length is at least its height ............................ C. peruana 2'. Presutural scutum and antepronotal ridge at same level as postpronotal carina. Pedicel not elongate, length is at most 1.5 times width. Occiput length is shorter than height ....

3. Prosternum wide, reaching the proepisternum laterally. Inner process of pedicel wide-triangular ............. 4 [Nerius Fabricius] 3'. Prosternum linear, separated from proepisternum by wide membranous area. Inner process of pedicel narrow triangular to finger-like 5 [Glyphidops Enderlein] 4. (3) Thorax with wide greyish stripe dorsally on presutural and postsutural scutum, divided by median narrow brown stripe. Inner vertical seta inconspicuous and outer vertical seta absent. Occiput inflated, mostly shiny N. pilifer

Table 1. List of species of Neriidae with distribution in the Brazilian Northeast Region. *=new records.

\begin{tabular}{|c|c|c|c|}
\hline Species & Northeastern Distribution & Other Brazilian records & Other countries distribution \\
\hline Cerantichir peruana & Maranhão* & Acre, Pará, Rondônia, Mato Grosso & Costa Rica, Colombia, Peru, Bolivia \\
\hline Eoneria blanchardi & Bahia, Paraíba, Pernambuco & Mato Grosso do Sul & Venezuela, Paraguay, Argentina \\
\hline Glyphidops durus & Maranhão* & $\begin{array}{l}\text { Amazonas, Amapá, Pará, São Paulo, } \\
\text { Paraná }\end{array}$ & $\begin{array}{l}\text { Costa Rica, Panama, Colombia, Venezuela, } \\
\text { Ecuador, Peru, Bolivia, Argentina }\end{array}$ \\
\hline Glyphidops flavifrons & Maranhão* & Amazonas, Pará, Acre, Espírito Santo & $\begin{array}{l}\text { USA (Arizona, Florida), Mexico, Honduras, } \\
\text { Nicaragua, Costa Rica, Panama, Trinidad and } \\
\text { Tobago, Guyana, Colombia, Ecuador, Bolivia }\end{array}$ \\
\hline Nerius plurivittatus & Maranhão* & Pará, Acre, Amazonas & $\begin{array}{l}\text { Mexico, El Salvador, Panama, Dominican } \\
\text { Republic, Trinidad, Guyana, Venezuela, } \\
\text { Colombia, Peru, Bolivia }\end{array}$ \\
\hline
\end{tabular}


4'. Thorax with two grey stripes dorsally on presutural scutum, separated by median wide brown stripe narrowing toward scutoscutellar suture, and one dorsocentral brown stripe on postsutural scutum. Inner and outer vertical setae welldeveloped. Occiput velvet pruinose ................. N. plurivittatus

5. Arista white entirely, or at least basal third, with dense white pubescence

5'. Arista brown and bare or with brown micropubescence .. 8

6. Pleuron yellowish-brown and partly yellow with katatergite yellow. Occiput with reduced ventral brown stripe. Abdomen dorsally with median yellow stripe from tergite 1 to tergite 6 or shorter G. flavifrons 6'. Pleuron brown with bluish reflections, even katatergite. Occiput with wide ventral brown stripe. Abdomen dorsally without median yellow stripe .... 7

7. Anterior notopleural seta hair-like and slender. Hind femur dorsally with two distomedian setae. Tibia yellow without brown ring ................................... G. carrerai 7'. Anterior notopleural seta absent. Hind femur dorsally without seta. Tibia yellow with distomedian pale brown ring, darker on mid and hind tibiae G. durus 8. Supra-alar seta present. Frontal vitta with two narrow black stripes in lateral margins anteriorly. Antennal base rounded and inflated; margins rounded in dorsal view G. vittatus 8'. Supra-alar seta absent. Frontal vitta with ovate black spot on posterior third, covering the ocellar triangle. Antennal base not inflated and at most slightly rounded G. filosus

\section{Cerantichir peruana (Hennig, 1937)}

Figures 1A, 1B and 3A

Diagnosis. Arista densely white pubescent; pedicel and scape elongate, being length at least twice the width; antennal base with inner margins close together; fronto-orbital plate shiny wide; ocellar triangle protrude; outer vertical setae absent; occiput shiny elongate and as long as high; vibrissa absent; thorax elongate, with mesoscutum and antepronotal ridge distinctly anterior to postpronotal carina; scapular seta present; posterior notopleural seta and apical scutellar seta inserted in a tubercle (adapted from Sepúlveda et. al. 2013b).

New records: BRAZIL - Maranhão: 1 , C. [=Centro] N.[Novo] Maranhão, Reserva Biológica Gurupi (REBIO), 03¹4'01"S, 4640'52"W, 01-06.iii.2011, F. Limeira-de-Oliveira, E. A. S. Barbosa \& F. Limeira-de-Oliveira; same locality: 1 , , 02-11.ix.2010, F. Limeirade-Oliveira, E. A. S. Barbosa \& M. M. Abreu; 1 क, 05-15.vi.2010, F. Limeira-de-Oliveira \& J. C. Silva; $1 \delta$ and 3 o ${ }_{+}, 05-15 . v i .2010$, F. Limeira-de-Oliveira, J. C. Silva \& D. W. A. Marques.

\section{Glyphidops durus (Cresson, 1926)}

\section{Figures 1C, 1D and 3D}

Diagnosis. Fronto-orbital setae increasing in size posteriorly, two anterior pairs closer than posterior pair; first flagellomere oblong with arista apical; posterior notopleural seta inserted on a small tubercle; scutum dorsally with two white pruinose stripes, separated by wide median brown stripe that widens and fades after transverse suture; katatergite brown; tibia yellow with median pale brown ring; halter yellow. (Sepúlveda et al. 2014).

New records: BRAZIL - Maranhão: $34 \hat{\delta} \widehat{\partial}$ and 57 우, Bom Jardim, Reserva Biológica Gurupi (REBIO) [-3.557624, -45.613928], 17-27.i.2010, F. Limeira-de-Oliveira, J. T. Câmara \& M. B. Aguiar Neto; same locality: 9 $\delta$ ô and 24 q , , 05-15.vi.2010, F. Limeira-de-Oliveira, J. C. Silva \& D. W. Marques; 1 Oૈ, 05-15.vi.2010, F. Limeira-de-Oliveira $\&$ J. C. Silva; $9 \hat{\delta} \delta$ and 17 우, 12.ix-30.x.2010, F. Limeira-de-Oliveira

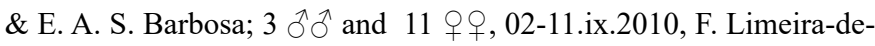
Oliveira, E. A. S. Barbosa \& M. M. Abreu; 3 우, 01-06.ix.2010, F. Limeira-de-Oliveira \& E. A. S. Barbosa; 1 ô, 07-15.i.2011, F. Limeirade-Oliveira \& D. W. A. Marques; 1 + , C. [=Centro] N.[Novo] Maranhão, Reserva Biológica Gurupi (REBIO), 0314'05"S, 46² $41^{\prime} 83^{\prime \prime} \mathrm{W}, 07-15$. xi.2011, F. Limeira-de-Oliveira \& E. A. S. Barbosa; same locality: 2 ठ઼ and 1 + , 01-06.iii.2011, E. A. S. Barbosa \& F. Limeira-de-Oliveira; 2 웅, 03-07.v.2011, E. A. S. Barbosa \& F. Limeira-de-Oliveira.

\section{Glyphidops filosus (Fabricius, 1805)}

Figures $1 \mathrm{E}, 1 \mathrm{~F}$ and $3 \mathrm{E}$

Diagnosis. Frontal vitta yellow with ovate black spot well delimited by color on posterior third and covering the ocellar triangle. First flagellomere lanceolate with arista apical; scutum with two white pruinose stripes dorsally, separated by one wide median brown stripe that narrows after transverse suture; supra-alar seta absent (Sepúlveda et al. 2014).

New records: BRAZIL-Ceará: $10 \hat{\jmath} \widehat{o}$ and 15 $q$, , Ubajara, Parque Nac.[=Nacional] de Ubajara, Cachoeira do Cafundó, 0350'13"S, $40^{\circ} 54^{\prime} 35^{\prime \prime} \mathrm{W}, 21-24 . i v .2012$, J. A. Rafael \& F. Limeira-de-Oliveira; same locality: 2 and 2 +, 22-24.iv.2012, O. H. H. Milke \& M. M. Casagrande. Maranhão: $2 \uparrow+$, Bom Jardim, Reserva Biológica Gurupi (REBIO) [-3.557624, -45.613928], 01-06.xi.2010, M. M. Abreu, E. A. S. Barbosa \& J. A. Silva; same locality: $1 \hat{\delta}$ and 23 우, 01-06.xi.2010, F. Limeira-de-Oliveira \& E. A. S. Barbosa; 1 đ and 5 우, 01-06.xi.2010, M. M. Abreu, E. A. S. Barbosa \& J. A. Silva; 26 ^ै and 41 우, 1727.i.2010, F. Limeira-de-Oliveira, J. T. Câmara \& M. B. Aguiar Neto; $3 \widehat{\partial} \widehat{\partial}$ and 3 우, 05-15.vi.2010, F. Limeira-de-Oliveira, J. C. Silva \& D. W. A. Marques; 1 §, 05-15.vi.2010, F. Limeira-de-Oliveira \& J. C. Silva; 1 đ̂, 05-16.i.2010, F. Limeira-de-Oliveira, J. C. Silva \& D. W. A. Marques; 1 , , 02-11.xi.2010, F. Limeira-de-Oliveira, E. A. S. Barbosa \& M. M. Abreu; 1 ठૈ, 02-11.xi.2010, F. Limeira-de-Oliveira, J. C. Silva \& D. W. A. Marques; 1 †, 12.ix-31.x.2010, F. Limeira-deOliveira \& E. A. S. Barbosa; 1 , , 05-15.vi.2010, J. C. Silva, J. A. Silva,

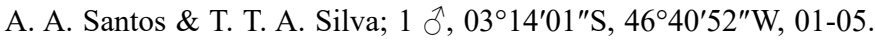
vii.2011, F. Limeira-de-Oliveira \& R. M. P. Campos; 1 ðै, 07-15.i.2011, F. Limeira-de-Oliveira \& D. W. A. Marques; 1 , 07-15.i.2011, F. Limeira-de-Oliveira \& M. M. Abreu; $13 \widehat{\partial} \widehat{\delta}$ and 14 우, C.[=Centro] N.[Novo] Maranhão, Reserva Biológica Gurupi (REBIO), 03¹4'05"S, $46^{\circ} 41^{\prime} 83^{\prime \prime}$ W, 03-07.v.2011, E. A. S. Barbosa \& F. Limeira-de-Oliveira; same locality: $7 \delta$ and 6 क, 01-06.iii.2011, E. A. S. Barbosa \& F. Limeira-de-Oliveira; 2 , , 07-15.xi.2010, F. Limeira-de-Oliveira \& E. A. S. Barbosa; 1 ơ and 4 우, $03^{\circ} 14^{\prime} 01^{\prime \prime}$ S, $46^{\circ} 40^{\prime} 52^{\prime \prime} \mathrm{W}, 03-07 . v .2011$, E. A. S. Barbosa \& F. Limeira-de-Oliveira; 1 ภ, 01-06.iii.2011, E. A. S. Barbosa \& F. Limeira-de-Oliveira; 1 , , Carolina, Parq.[=Parque] Nac.[=Nacional] Chapada das Mesas, Riacho Cancela, 225m, 20-30. ix.2013, J. A. Rafael \& F. Limeira-de-Oliveira. Piauí: 1 ㅇ, Piracuruca, P.[=Parque] N.[=Nacional] de Sete Cidades, Posto ICMBio, 17-19. vii.2012, $04^{\circ} 05^{\prime} 57^{\prime \prime}$ S, $41^{\circ} 42^{\prime} 34^{\prime \prime}$ W, J. S. Pinto Júnior \& J. A. Rafael. 
Sepúlveda, T.A. et al.

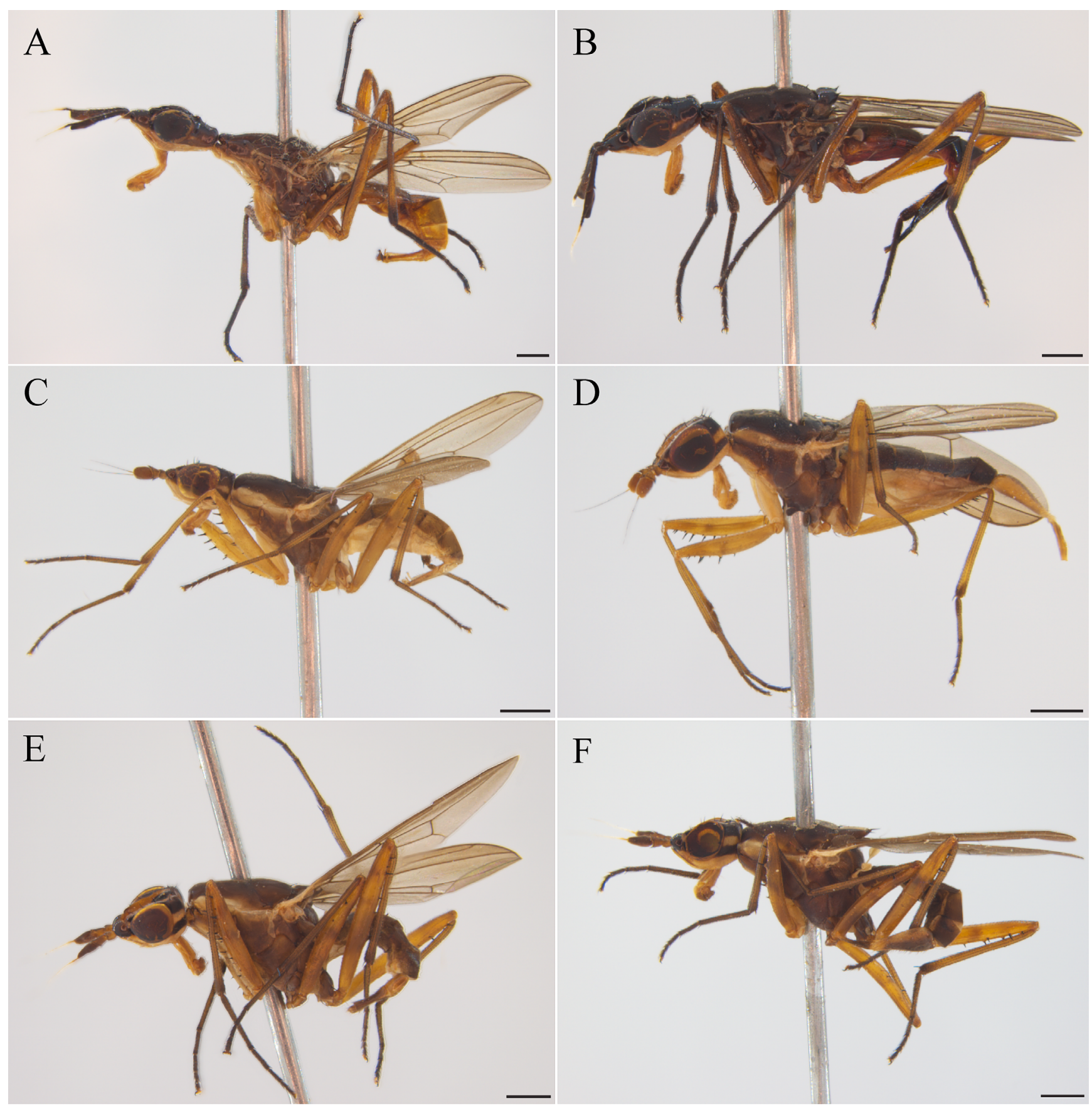

Figure 1. Habitus in lateral view. Cerantichir peruana (Hennig, 1937), male (A) and female (B). Glyphidops durus (Cresson, 1926), male (C) and female (D). Glyphidops filosus (Fabricius, 1805), male (E) and female (F). Scale bars $=1 \mathrm{~mm}$.

\section{Glyphidops flavifrons (Bigot, 1886)}

\section{Figures 2A, 2B and 3F}

Diagnosis. Frontal vitta yellow; first flagellomere oblong with arista apical; ocellar triangle blackish-brown, contrasting by color with the yellow frontal vitta; scutum dorsally with two white pruinose stripes, separated by one wide median brown stripe that narrows after transverse suture; pleuron variable in color, from pale brown to entirely yellow; katatergite yellow (Sepúlveda et al. 2014).
New records: BRAZIL - Maranhão: $7 \widehat{\partial} \delta^{\lambda}$ and 15 $\phi$ + , Bom Jardim, Reserva Biológica Gurupi (REBIO) [-3.557624, -45.613928], 05-15.vi.2010, F. Limeira-de-Oliveira, J. C. Silva \& D. W. A. Marques; same locality: $5 \hat{\delta}$ and 12 우, 17-27.i.2010, F. Limeira-de-Oliveira,

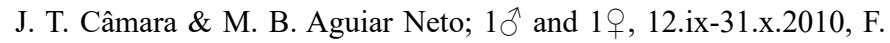
Limeira-de-Oliveira \& E. A. S. Barbosa; 1 9 , 05-06.xi.2010, F. Limeirade-Oliveira \& E. A. S. Barbosa; $3 \hat{\delta} \widehat{\partial}$ and 7 우, 02-11.xi.2010, F. Limeira-de-Oliveira, E. A. S. Barbosa \& M. M. Abreu; 1 đ , C. [=Centro] 
Neriidae of the Northeastern Brazil

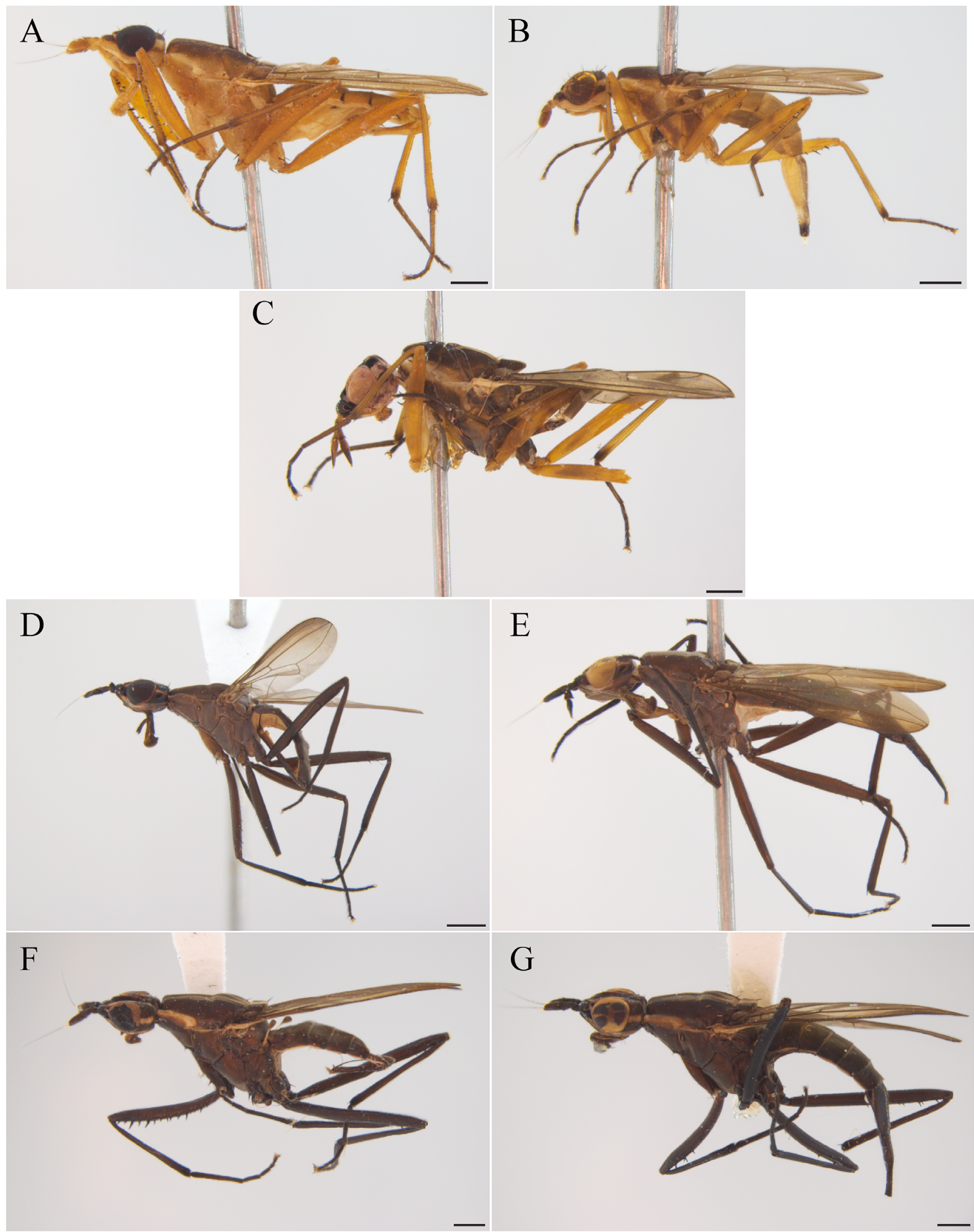

Figure 2. Habitus in lateral view. Glyphidops flavifrons (Bigot, 1886), male (A) and female (B). Glyphidops vittatus (Cresson, 1912), male (C). Nerius pilifer Fabricius, 1805, male (D) and female (E). Nerius plurivittatus Bigot, 1886, male (F) and female (G). Scale bars $=1 \mathrm{~mm}$. 

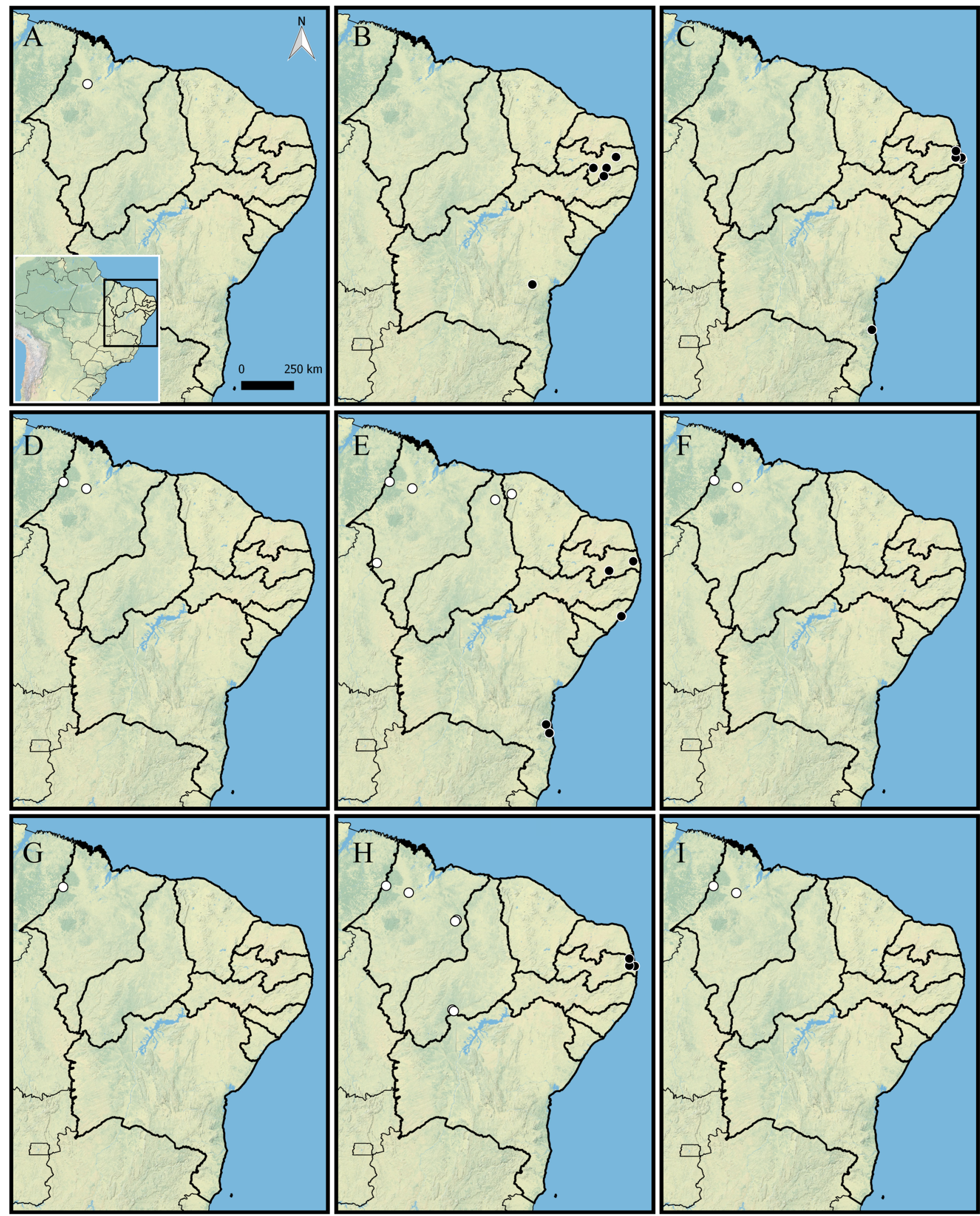

Figure 3. Distribution records of Neriidae in the Brazilian Northeast Region. Cerantichir peruana (Hennig, 1937) (A); Eoneria blanchardi Aczél, 1951 (B); Glyphidops carrerai Aczél, 1961 (C); Glyphidops durus (Cresson, 1926) (D); Glyphidops filosus (Fabricius, 1805) (E); Glyphidops flavifrons (Bigot, 1886) (F); Glyphidops vittatus (Cresson, 1912) (G); Nerius pilifer Fabricius, 1805 (H); Nerius plurivittatus Bigot, 1886 (I). White circle (new records); black circle (records from literature) 
N.[=Novo] Maranhão, Reserva Biológica Gurupi (REBIO), 03¹4'05"S, 46 41'83"W, 01-06.iii.2011, E. A. S. Barbosa \& F. Limeira-de-Oliveira.

\section{Glyphidops vittatus (Cresson, 1912)}

Figure $2 \mathrm{C}$ and $3 \mathrm{G}$

Diagnosis. Head not elongate in lateral view; first flagellomere lanceolate with arista apical; frontal vitta yellow with two narrow black spots laterally near anterior margin and one triangular blackish-brown spot posteriorly, in front of the ocellar triangle; fronto-orbital plate shiny black; antennal base inflated, with lateral and distal margins rounded in dorsal view; scutum dorsally with two white pruinose stripes, separated by one narrow median brown stripe that narrows and fades after transverse suture; supra-alar seta present (Sepúlveda et al. 2014).

New records: BRAZIL - Maranhão: $3 \hat{\delta} \hat{\partial}$, C. [=Centro] N.[=Novo] Maranhão, Reserva Biológica Gurupi (REBIO), $03^{\circ} 14^{\prime} 01^{\prime \prime} \mathrm{S}$, $46^{\circ} 40^{\prime} 52^{\prime \prime} \mathrm{W}, 01-06.1 i i .2011$, E. A. S. Barbosa \& F. Limeira-de-Oliveira.

\section{Nerius pilifer Fabricius, 1805}

Figures 2D, 2E and $3 \mathrm{H}$

Diagnosis. Scape and pedicel brown, antennal base shiny and dark brown; frontal vitta red-ferruginous, with one central brown band from the middle to posterior region; occiput shiny; thorax brown with pale pruinescence; thorax in dorsal view with one wide grayish stripe, separated by a median brown stripe very thin; anterior notopleural seta reduced; basicosta with one small seta; one dorsocentral seta; legs dark brown; fore femur with outstanding anteroventral row of spines (Aczél 1951).

New records: BRAZIL - Maranhão: 5 q+ , Bom Jardim, Reserva Biológica Gurupi (REBIO) [-3.557624, -45.613928], 05-15.vi.2010, F. Limeira-de-Oliveira, J. C. Silva \& D. W. A. Marques; same locality: 1 q, 13-27.i.2010, F. Limeira-de-Oliveira, J. T. Câmara \& M. B. Aguiar Neto; 1 q, 12.ix-31.x.2010, F. Limeira-de-Oliveira \& E. A. S. Barbosa; 1

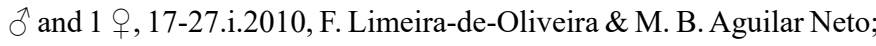
2 우, 02-11.ix.2010, F. Limeira-de-Oliveira, E. A. S. Barbosa \& M. M. Abreu; $5 \widehat{\delta} \widehat{\delta}$ and 29 우, C. [=Centro] N.[=Novo] Maranhão, Reserva Biológica Gurupi (REBIO), 03¹4'05"S, 46²1'83"W, 03-07.v.2011, E. A. S. Barbosa \& F. Limeira-de-Oliveira; same locality: 1 $\delta$ and 2 우, 01-06.iii.2011, E. A. S. Barbosa \& F. Limeira-de-Oliveira; $1 \hat{\jmath}$, $03^{\circ} 14^{\prime} 01^{\prime \prime S}, 46^{\circ} 40^{\prime} 52^{\prime \prime} \mathrm{W}, 03-07 . v .2011$, E. A. S. Barbosa \& F. Limeirade-Oliveira; $5 \delta^{\top} \delta^{\prime}$ and 6 우, Caxias, 04 $52^{\prime} 43^{\prime \prime} \mathrm{S}, 43^{\circ} 19^{\prime} 31^{\prime \prime} \mathrm{W}, 01-15$. viii.2017, F. Limeira-de-Oliveira \& D. Limeira; same locality: 6 $\widehat{\partial}$ and 15 우, 23-31.vii.2017, F. Limeira-de-Oliveira \& D. Limeira; 1 +, Caxias, 04 $51^{\prime} 19^{\prime \prime} \mathrm{S}, 43^{\circ} 20^{\prime} 33^{\prime \prime} \mathrm{W}, 01-15 . v i i i .2017$, D. Limeira \& D. P. Silva; 1 , Caxias, 04 ${ }^{\circ} 52^{\prime} 11^{\prime \prime} \mathrm{S}, 43^{\circ} 20^{\prime} 48^{\prime \prime} \mathrm{W}, 15-31 . v i i .2017$; 2 우오 Caxias, $04^{\circ} 54^{\prime} 43^{\prime \prime} \mathrm{S}, 43^{\circ} 25^{\prime} 30^{\prime \prime} \mathrm{W}$, Caxias, Reserva Inhamum, 01.viii.2011, J. T. Câmara, T. M. S. Coutinho. Piauí: 1 †, Caracol, Parq. [=Parque] Nac.[=Nacional] Serra das Confusões, 09¹3'11.9"S, $43^{\circ} 29^{\prime} 26.2^{\prime \prime} \mathrm{W}, 575 \mathrm{~m}, 15-31 . v i i .2013$, J. A. Rafael, F. Limeira-deOliveira \& T. T. A. Silva; same locality: 1 तै and 3 우, 20-31.iii.2014, J. A. Rafael, F. Limeira-de-Oliveira, T. L. Rocha \& G. A. Reis; 2 $\delta^{\lambda} \hat{\sigma}^{\prime}$, Guaribas, Parque Nacional Serra das Confusões, $09^{\circ} 08^{\prime} 27.8^{\prime \prime} \mathrm{S}$, $43^{\circ} 33^{\prime} 42.1^{\prime \prime} \mathrm{W}, 515 \mathrm{~m}, 10-20 . i x .2014$, J. A. Rafael, T. L. Rocha \& G.

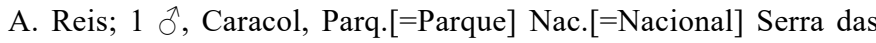
Confusões, 09¹2'48.9"S, 4327'59.9"W, 705m, 01-10.ix.2014, J. A. Rafael, F. Limeira-de-Oliveira, T. L. Rocha \& G. A. Reis.

\section{Nerius plurivittatus Bigot, 1886}

Figures 2F, 2G and 3I

Diagnosis. Antennal base shiny; distal margin slightly concave in dorsal view; occiput opaque with one median yellow stripe; thorax in dorsal view with one wide grayish medially divided by one median brown stripe and by intra-alar stripe in postsutural scutum; frontoorbital plate slightly pruinose, with anterior half yellow and posterior half brown.

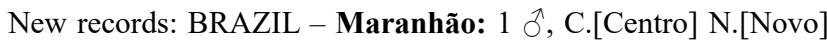
Maranhão, Reserva Biológica Gurupi (REBIO), 03¹4'05"S, $46^{\circ} 41^{\prime} 83^{\prime \prime} \mathrm{W}, 01-06 . i i i .2011$, E. A. S. Barbosa \& F. Limeira-de-Oliveira; 1 ô, Bom Jardim, Reserva Biológica Gurupi (REBIO) [-3.527534, -46.680510], 12.ix-31.x.2010, F. Limeira-de-Oliveira \& E. A. S. Barbosa; same locality: 1 ô, 02-11.ix.2010, F. Limeira-de-Oliveira, E. A. S. Barbosa \& M. M. Abreu; 1 , , 02-11.ix.2010, F. Limeira-deOliveira \& J. C. Silva.

\section{Discussion}

In the revision of the Glyphidops, Sepúlveda et al. (2014) revalidated G. vittatus from synonymy with G. filosus, based on a variety of characters present in G. vittatus and absent in G. filosus. These characters include the antennal base inflated with rounded margins, head not elongate in lateral view and supra-alar seta present. We have found that G. filosus also bears a very well-defined ovate black spot surrounding the ocellar triangle, which is absent in G. vittatus, making both species easily distinguishable. Braga et al. (2017) followed the classification of Glyphidops as used by Koch et al. (2015), which considers $G$. vittatus as a junior synonym of G. filosus. However, Braga et al. (2017) noticed the presence of an ovate black spot covering the ocellar triangle and the lack of supra-alar seta in the material they determined as $G$. filosus. Here, as we follow the classification proposed by Sepúlveda et al. (2014), the characters cited by Braga et al. (2017) for G. filosus, allowed us to confirm that the specimens studied by the authors are not G. vittatus. Thus, although Braga et al. (2017) cited new records for $G$. filosus considering it as senior synonym of $G$. vittatus, we can say with confidence that the localities recorded by these authors correspond to G. filosus sensu Sepúlveda et al. (2014).

Carvalho-Filho \& Esposito (2008) presented a key for the identification of Neriidae from the Brazilian Amazon with 10 species recorded for this area, one of which, G. flavipes (Wiedemann), is considered a species inquirendum (Steyskal, 1968) and one other species, $N$. dispar Cresson, has been proposed as a junior synonym of G. durus (Sepúlveda et al. 2014). In a subsequent publication, Sepúlveda et al. (2014), recorded G. vittatus and G. steyskali Sepúlveda, Wolff \& de Carvalho for the Brazilian Amazon, restoring the number of species of Neriidae known from the Brazilian Amazon to 10. Of these species recorded for the Brazilian Amazon, we did not find G. steyskali nor $G$. limbatus, but all the other species in this region are also present in the Northeast and presented in Table 1, revealing a mostly homogenous distribution of species of Neriidae within the northern part of the country.

This survey updated the distributional knowledge of the Neriidae from the Brazilian Northeast (Figure 3). It adds a substantial number of records to the area, totalizing 10 new records to the states of Ceará (1 new record), Maranhão (7 new records) and Piauí (2 new records). 
Also, the records of G. filosus in Ceará and Piauí, and N. pilifer in Piauí are the first records of these species in the Brazilian Semiarid. Before our survey, E. blanchardi was the only record of Neriidae in the semiarid area, in the Bahia, Paraíba and Pernambuco states (Braga et al. 2017). Our faunistic survey enables a range of possibilities for further studies, mainly in ecology and biogeography of the Brazilian Northeast and its biomes.

\section{Author Contributions}

Tatiana A. Sepúlveda, prepared the manuscript and participated in data collection;

Lucas R. P. Gomes, made a substantial contribution to the concept and design of the study and participated in data collection;

Francisco Limeira-de-Oliveira, made a substantial contribution to the concept and design of the study and participated in data collection;

All authors contributed with data analysis and interpretation, made critical revision and added intellectual content.

\section{Conflict of interest}

The authors declare that they have no conflicts of interest related to the publication of this manuscript.

\section{References}

ACZÉL, M.L. 1951. Morfologia externa y división sistemática de las "Tanypezidiformes" con sinopsis de las espécies argentinas de "Tylidae" ("Micropezidae") y "Neriidae" (Dipt.). Acta Zool. Lilloana 11:483-589 +4 pls.

ACZÉL, M.L. 1961. A revision of American Neriidae (Diptera, Acalyptratae). Stud. Entomol. 4:257-346.

BRAGA, I. S., PEREIRA-COLAVITE, A. \& CREÃO-DUARTE, A.J. 2017. New distribution records for Neriidae (Diptera, Schizophora) from northeastern Brazil. Check List 13:1-5.

BUCK, M. 2010. Chapter 56. Neriidae. In Manual of Central American Diptera (B.V. Brown, A. Borkent, J.M. Cumming, D.M. Wood, N.E. Woodley, M.A. Zumbado, eds.). NRC Research Press, Ottawa, v.2, p.815-819.
CAlhau, J., Pereira-Colavite, A., Sepúlveda, T.A., DE CARVALHO, C.J.B., DE ARRUDA, P.M., NIHEI, S.S., KOSMANN, C., PUJOL-LUZ, C.V.A., PUJOL-LUZ, J.R. 2017. Checklist of the Heleomyzidae, Neriidae and Oestridae (Insecta, Diptera) in the State of Mato Grosso do Sul, Brazil. Iheringia, Sér. Zool. 107:1-5.

CARVALHO-FILHO, F.S. \& ESPOSITO, M.C. 2008. Neriidae (Diptera: Schizophora) of the Brazilian Amazon: new records of genera and species, and key to species. Neotrop. Entomol. 37:58-62.

KOCH, N.M., SOTO, I.M. \& RAMÍREZ, M.J. 2015. First phylogenetic analysis of the family Neriidae (Diptera), with a study on the issue of scaling continuous characters. Cladistics 31:142-165.

MORRONE, J. 2015. Biogeographical regionalization of the world: A reappraisal. Aust. Syst. Bot. 28:81-90.

PAPE, T., BLAGODEROV, V. \& MOSTOVSKI, M.B. 2011. Order DIPTERA Linnaeus, 1758. In Animal biodiversity: An outline of higher-level classification and survey of taxonomic richness (Z.Q. Zhang, ed.). Zootaxa 3148:222-229.

SEPÚlVEDA, T.A., WOLFF, M.I. \& DE CARVALHO, C.J.B. 2013a Revision of the Neotropical genus Eoneria Aczél (Diptera: Neriidae) with description of a new species from Colombia. Zootaxa 3636:245-256.

SEPÚLVEDA, T.A., PEREIRA-COLAVITE, A. \& DE CARVALHO, C.J.B. 2013b. The Neotropical genus Cerantichir Enderlein (Diptera, Neriidae): redescriptions, key and new records. Rev. Colomb. Entomol. 39:125-131.

SEPÚLVEDA, T.A., WOLFF, M.I. \& DE CARVALHO, C.J.B. 2014. Revision of the New World genus Glyphidops Enderlein (Diptera: Neriidae). Zootaxa 3785:101-138.

SEPÚLVEDA, T.A. 2019. Neriidae. In Catálogo Taxonômico da Fauna do Brasil (CTFB). Available at: <http://fauna.jbrj.gov.br/fauna/faunadobrasil/2287>. Last access: 18 Nov. 2019.

SEPÚlVEDA, T.A. \& DE CARVALHO, C.J.B. 2019. Chaetonerius Hendel (Diptera: Neriidae) from the East African islands with description of four new species from Madagascar and the Comoros. Zootaxa 4567:130-146.

SEPÚLVEDA, T.A. \& SOUZA, D.S. 2019. A new species of Chaetonerius Hendel (Diptera: Neriidae) from Northeast Madagascar. Zootaxa 4656:389-392.

SEPÚlVEDA, T.A., SOUZA, D.S., GOMES, L.R.P., FOGAÇA, J.M. \& DE CARVALHO, C.J.B. 2019. The Neriidae (Diptera) of Southeast Asia: A taxonomic revision of the genus Telostylus. European Journal of Entomology 116:281-301.

STEYSKAL, G.C. 1968. Family Neriidae. In A catalogue of Diptera of the Americas South of the United States (N. Papavero, ed.). Secretaria da Agricultura de São Paulo, Departamento de Zoologia, São Paulo, v.49, p. 1-7. 